Millei, Z. \& Rautio, P. (2017) 'Overspills' of research with children: an argument for slow research. Children's Geographies. http://dx.doi.org/10.1080/14733285.2016.1277182

\title{
'Overspills' of Research with Children: An Argument for Slow Research
}

Zsuzsa Millei, Institute for Advanced Social Research, University of Tampere,

Finland

Pauliina Rautio, University of Oulu, Finland

\begin{abstract}
We take on the challenge posed by Horton \& Kraftl (2006b, p. 71) that research be 'slowed down' through methodological and theoretical routes to acknowledge seemingly trivial details in children's lives. Based on an ethnographic study in an Australian preschool focusing on children's place-making in a globalizing world, this paper discusses one event in the home corner to exemplify what we understand as and how we enact methodological slowness. The event is revisited by recognising the role of the unexpected, the troubling and paying attention to data that overspills the research engagement in conducting 'ideally preset qualitative research'. Research engagements not only reflect but also produce children's lives. Researching 'the global' is 'doing the global' as the frames, practices and traditions of research itself are part and parcel of the so-called answers we produce. As result, a more nuanced and complex understanding of how 'the global' is made and circulated by children surfaces.
\end{abstract}

\section{Keywords:}

slow research, overspill, data glow, global, place-making

"Living is full of encounters and events that intrigue and provoke us"

(St Pierre 2013, 226).

This article is a bid to do research differently, slowly, as part of children's everyday 
Millei, Z. \& Rautio, P. (2017) 'Overspills' of research with children: an argument for slow research. Children's Geographies. http://dx.doi.org/10.1080/14733285.2016.1277182

life, and uses an event in the home corner ${ }^{1}$ of an Australian preschool $^{2}$ to exemplify how I attempted to do that. I follow in my work Horton and Kraftl (2006b, p. 70 following Massey) and Michael (2012 following Stengers) who suggest methodological slowness. Since their original call for slow research, many have taken up this challenge $\mathrm{s}^{3}$ and in this paper $\mathrm{I}^{4}$ continue this work. I revisit and reframe the home corner event by slowing down, rewinding and paying attention to what Svend Brinkmann (2014) calls 'break-downs' and Mike Michael (2012, 528) terms 'overspills'. While I address some methodological issues that concern how this kind of slow research might be done, I also re-present the event by applying a different frame so as to provide a complex and layered understanding of how children's placemaking in a globalizing world perhaps could be better approximated.

\section{Place Making in the Home Corner: First Approximation}

The research concerned is about children's place-making in a globalizing world. It aims to demonstrate that even though children's lives are dominantly studied at the smaller scales, their everyday life is shaped by processes that happen at larger scales ${ }^{5}$

\footnotetext{
1 A home corner is an area separated usually in any preschool to play with miniature home equipment and enact stories of family life.

2 In New South Wales, Australia, preschools are state or community provisioned and operate during the same hours as schools, from $9 \mathrm{am}-3 \mathrm{pm}$. Dominantly 4 but also 3 years old children are enrolled for a couple of days during the week. They teach the national early learning curriculum and are nationally regulated. Preschools are generally small, including a few teaching rooms with about 20-25 children in each who are taught and cared for by two educators (one educator is either a 4 year university trained teacher or 3 year diploma trained educator which is gained at a technical and further education institution and another educator who has 6 months long certificate of child care).

3 For example, the special issue edited by Horton, Kraftl, \& Tucker [2008]; children being caught up in research by Pyer [2008]; rhythmanalysis of school journeys by Kullman \& Palludan, [2011]; about the banality of everyday by Rautio [2013]; emotional events that 'haunt' and return in research by Hadfield-Hill \& Horton [2014]; and openness, messiness and ongoingness by Pyyry [2015] to list but a few who engaged with the challenge in this journal.

4 The 'I' engaged in the actual research per se is the first author. However, this paper is a result of collaboration between both authors: of reconfiguring, retheorising and re-analysing in retrospect the events the first author and her research participants had gone through.

5 I do not want to propose a scale-based view of space here, rather argue that popular views on children's engagements with the world use these limiting notion of place. I am rather in agreement with Massey's
} 
Millei, Z. \& Rautio, P. (2017) 'Overspills' of research with children: an argument for slow research. Children's Geographies. http://dx.doi.org/10.1080/14733285.2016.1277182

(Ansell 2009). From this broader project on place-making, I selected to discuss in this article a single event. My original fieldwork diary makes note of this exemplary event the following way ${ }^{6}$ :

Lucas told me a story about his brother's travels, he then drew a map for me and explained his trip to North America and New Zealand and then showcased his knowledge about different global signs and symbols that he has learned by using a game on his grandmother's ipad. He also told me about flags of different nations, he knew them all. We started the discussion because a teacher told me that 'Lucas has something for you' and we sat down first in the activity area buzzing with children. Because that place got too busy we moved to the home corner to quietly chat but Iolanda and Kaden wanted to join in and made the discussion a mess. I have recorded the conversation on my voice recorder and kept drawings the children made.

In the event Lucas showed tremendous knowledge about global symbols and locations on the map of the world related to his brother and his own travels. He demonstrated that very young children can have a global imagination and they bring that into preschool. I was adamant to keep my focus on Lucas because his input seemed valuable whereas the other children caused a disturbance to my research efforts. It seemed I was at the a priori point I intended to reach and so the event felt like a success. However, the more I dwelt with what had happened, the more I felt compromised, uneasy and emotional, and the situation kept intriguing me. Were the other children just disrupting our discussion or did they have something to add to my research? Who was I (who or what made me) to brush these children off when they so obviously wanted to participate in what I was doing (research or otherwise)? What have I learned from this interview, and is that any different to what I knew before?

The above is an example of how frames, practices and traditions of research themselves are part and parcel of the so-called answers we produce to the questions

(1991) approach who proposed a relational view of space where space is bound into local and global networks that act to configure particular local places. (Massey 1991, 29).

${ }^{6}$ Children's names are real names and they and their families have chosen to use those in publications. 
Millei, Z. \& Rautio, P. (2017) 'Overspills' of research with children: an argument for slow research. Children's Geographies. http://dx.doi.org/10.1080/14733285.2016.1277182

we researchers ask ourselves (Michael 2012). It also exemplifies what Maggie MacLure $(2013,228)$ explains as "entangled relation of data-and-researcher", and what Svend Brinkmann (2014) labels as 'break-down driven research' - both recognising the role of the unexpected, the troubling and the overspills in conducting ‘ideal qualitative research’ (Brinkmann 2014, 722). What had initially felt like a successful field event in my research, a few hours later turned into disquieting oversights on my part: I silenced children, those whom seemed to me inapt during the event. This event, producing data this way and the data I have produced, grabbed and fascinated me, and the strong emotions evoked triggered me to answer the question: 'What was I busy doing' as research? (Michael 2012). This kind of intensity that emanates from data is termed by Maggie MacLure (2013) as 'glow' or 'wonder of data', where data seems to reach out to grasp the researcher and form a data-andresearcher relation.

Following Law \& Mol's (2002) expression, the home corner event initially fell neatly within the argumentative logic of my research plan and questions projected (to find answers for). Or rather, as Michael $(2012,529)$ explains, I sanitized the event, I "cleaned up so that the existing methodological, conceptual, and institutional frames of the engagement event remain unchallenged". It seemed other details did not matter. Horton and Kraftl $(2006 \mathrm{~b}, 72)$ in unison add: "ironically, our research efforts focus only on those bits that seem worth the effort, that have an a priori point; that facilitate grand theories, 'useful' explanations, or poignant political polemic". As a result, "many aspects of our lives too often go unrecorded, disregarded and uncared for" (Horton and Kraftl 2006b, 71). At other times, "too-much of what we [researchers and children] do is ignored, because it seems too mundane, too obvious, too pointless, or 
too insignificant to write about, explain, even think about". However, maybe those very points and most mundane events or details are the ones that could help us learn something new.

In the home corner event in this research, an unnerving amount of aspects and even children went disregarded and uncared for as I stayed focused on things that I thought 'worth the effort'. What made me realise this is the emotional turmoil that I have experienced after coming home from the preschool. The same way as I felt gratitude for Lucas helping with the 'data production', I felt terrible about hushing away other children who tried to be with us. I felt paralysed which slowed down the research. I remained captive of this event, data and its intensity.

\section{Exclusions}

The way the event was originally captured recognize only the child who was able to show me something of the 'global' (according to my definition at that time). This knowledge made me select him as a participant in my research. I understood exhibiting a knowledge of distant places, names, trademarks, symbols etc. as a marker of children's 'globalness', a frame that I have knowingly applied. At the same time this frame also highly limited what and who I have included in my research, limiting the number and scope of engagements I considered meaningful for my research. According to this frame, Iolanda and Kaden were irritants, haunting the frame, "a rumbling of the repressed, so to speak" (Michael 2012, 534). The emotions that this event in the home-corner provoked made me question my own empirical, analytical and political presumptions, the very framing of my research. 
In research with children, "research processes continually constitute affective geographies through conversations, encounters, incidents, practices, and exchanges of material objects" (Hadfield-Hill \& Horton 2014, 135-135). I especially felt guilty about excluding children - Iolanda and Kaden. How could I maintain my position as a researcher who considers children as participating on equal grounds? I also felt for Lucas, both as a talented young child who obviously knew far more about the world than someone expects of a 4 year-old boy and as a 'productive' participant who can help me get along with my study. At other times I had difficulty making him stop following me with his never ending stories of travels. I always felt an urge while in the preschool to produce data so to not waste time. At times the days seemed productive which made me happy. At other times I was frustrated because it felt that I just played with children in a quest to reciprocate their willingness to partake in my research. I was concerned about my 'scientific intervention' in the spaces of childhood and preschool, was this preschool a global place or I am the one who brought this agenda here? Would Lucas talk to me about other things if I was not interested in the global, perhaps more 'childish' topics than locating towns on the map and drawing the symbol of Apple? As one educator noted referring to my accent, the many places I have lived and cultures I represented: "you are the most global thing in here".

The intensity of feelings aroused by this event made me wonder and kept me in this space. I occupied a "liminal condition, suspended in the threshold between knowing and unknowing, that prevents wonder from being wholly contained or recuperated as knowledge, and this affords an opening onto the new" (MacLure 2013, 228). 
Millei, Z. \& Rautio, P. (2017) 'Overspills' of research with children: an argument for slow research. Children's Geographies. http://dx.doi.org/10.1080/14733285.2016.1277182

Questions kept haunting me: What (absent) presences and elements (materials, relations, spaces) in the event and place of the home corner escaped my attention and notes (thus overspilled the engagement)? (Michael 2012, 535) What made me disregard or not 'see' and record those? How might what have overspilled the event be made more available as data? What is the global? How else I could understand it that would make me include those children and entities that I left out?

\section{Inclusions}

The notion of 'overspill' by Mike Michael (2012, 528) became crucial in reconsidering the home corner event and will remain as the conceptual tool of this paper. Michael describes 'overspills' as that which does not fit the intended or possible framing of the research: "engagement events-whether interviews, installations, or participatory encounters — can entail a range of happenings which, in one way or another, 'overspill' the empirical, analytic, or political framing of those engagement events" (Michael 2012, 528). As many have insisted before and after him (for example Law \& Mol, 2002) there is a need to question the frames that sanitize the research process by 'cleaning up' the engagements portrayed (Michael 2012, 529). So the task becomes one of how to catch overspills, which overspills to go after and what to do with them?

I used overspills in two ways. Firstly, rather than neatly discard, I reinserted the overspills into my 'data' - the interruptions, complexities, irrelevant remarks, postures and gestures as part of the studied phenomenon - children's place-making in a globalizing world. However, doing so made the event strange, it did not make sense. 
Millei, Z. \& Rautio, P. (2017) 'Overspills' of research with children: an argument for slow research. Children's Geographies. http://dx.doi.org/10.1080/14733285.2016.1277182

As Brinkman (2014) explains, there is 'data' that make the researcher stumble, become unbalanced due to a break-down in understanding. I made myself stay in this uncomfortable space and sustained searching and thinking in hope that it might lead me to make new sense. Brinkmann (2014) terms this 'abduction', when the data abducts the researcher in a continuous sense-making process. Second, the overspill helped me recognize that the frame I have been using was limiting. The frame made me to smoothly discard children and entities. Therefore, I used overspills as indicators of the frame to which they do not fit within: of how knowledge is meant to be produced, of how research is meant to be carried out, including my existing methodological and conceptual frames of the research (Michael 2012).

\section{Framing the research engagement}

At the start of my research and during the time this event occurred in the home corner, I understood the globalizing world, of which this pre-school is a part of, as cultural flows; mobilities of people, objects and ideas; and 'soft' and 'hard' forms of power ('hard' forms such as legislations, market mechanisms) that reconstitute how people make their place, view the world, the self and Other (Delanty 2006). To understand the ways in which children's spheres of experience in the preschool are determined by global dynamics, events that effect the world, such as financial crisis or global terrorism, I specifically focused on "global promotions, values, networks, global longings, trademarks, symbols, which spread in the most diverse ways" (Beck and Beck-Gernsheim 2002, 25). I entered the preschool with the aim to 'collect' stories of children's place-making in this globalising world so to prove that they also partake in larger processes of globalisation. I set the study against others who explore children's everyday life within the institutions they dwell in (such as family, preschool, school) 
Millei, Z. \& Rautio, P. (2017) 'Overspills' of research with children: an argument for slow research. Children's Geographies. http://dx.doi.org/10.1080/14733285.2016.1277182

without considering larger processes that shape those very institutions and children's everyday lives within them. These stories would have served to argue against research methodologies that posit children's actions on a small or local scale (Ansell, 2009) and as less important members of and participants in society.

I employed a particular ethics of engagement with children that is based on the Convention on the Rights of the Child and is highly valued in childhood studies. I considered children as competent agents whose voice needs to be heard in research (James \& Prout 1997). I was also careful to approach children as equal as possible with me, who can agree or reject being or conversing with me at any time and who can withdraw consent from research at any moment. Still I, as the researcher, invited child participants to converse with me, to allow me to record as research data what we discuss, but only proceeded if they have given their consent. It seems that who and what have entered into the research was still decided only by me.

I went on to identify aspects of children's place-making in 'the empirical world', only to discover that I 'found' nothing new. As Brinkmann $(2014,722)$ duly notes: an expression or way of thinking about 'the empirical world' is troubling: "for who has ever visited the unempirical world?" Drawing on Dewey's words he argues that "data are always produced, constructed, mediated by human activities" or 'taken' from the original subject matter under study, discriminated for the purpose to know. In this way data is 'sense data' that helps to define or give evidence to the originally framed problem and provides ideas for resolution. If we have it that there is no "data" to be "collected", from "out there" rather it is created (a 'creata'), as the currently growing approach of post-qualitative inquiry also has it (e.g., St. Pierre 2013, Koro-Ljungberg 
Millei, Z. \& Rautio, P. (2017) 'Overspills' of research with children: an argument for slow research. Children's Geographies. http://dx.doi.org/10.1080/14733285.2016.1277182

\& MacLure 2013), then there is no 'researcher' as a separate agent either who objectively perceives and records reality. And so the researcher has to be a dynamic agential part of the research assemblage rather than only a removed observer or influence.

In sum, my research frame was created by at least four distinct assumptions: first, I had a concept of the 'global' that made me 'sense' data in a way that identified symbols, signs, ideas, objects, people that were on the move as part of the global. I acted as a removed researcher from what was happening in the preschool and identified and shut out many different views to what that sense of the global or globalization entailed. Second, and relatedly, I identified children as participants who presented me with 'evidence' for this view, for example, who manipulated 'global' signs or objects, expressed knowledge about distant places or had experiences with people living elsewhere. These children became research participants, while others were disregarded. Moreover, third, only those children who came to me, I came across or teachers alerted me about, and gave their consent and voiced their views about the global were included in the research. Those who acted on the side, who remained silent but were there, who performed seemingly unrelated activities were not included. Fourth, I have progressed in a linear way by initially creating a conceptual framework, then moving into the setting, collecting data and finishing by analyzing. This is a form of deductive research and analysis, a process governed by proof seeking, where a theoretical framework has guided my 'sensing' of data and analysis through which I have re-presented the 'empirical world', children's placemaking. However, this deductive model of research did not help me navigate my concerns that initially, but perhaps less explicitly motivated my research, the 
Millei, Z. \& Rautio, P. (2017) 'Overspills' of research with children: an argument for slow research. Children's Geographies. http://dx.doi.org/10.1080/14733285.2016.1277182

existential, moral and political dilemmas I started off with: children considered and approached as lesser members of society though they are equally important participants in society, including research.

\section{Re-framing the event}

To begin to reframe the event in the home corner I narrate or story the event anew. In this narration, the past of the home corner event together with the emotions it evoked, the researcher, and the analytical encounter with the 'material' become mixed (Revsbæk \& Tanggaard 2015). In other words, I work with and rework 'data', method, representation and the becoming of the researcher further in the spirit of Jackson \& Mazzei (2012, ix) when they argue that data are always "partial, incomplete, and always in a process of a re-telling and re-membering”. The following is a reconsideration and an affective approximation of the home corner event based on 1) the original fieldnotes, recordings, and drawings by children; 2) later readings/recollections and discussions with other scholars; 3) key readings, especially by Maggie MacLure (2013) and Svend Brinkmann (2014); and 4) inspiration from Stuart Aitken's (2014) ethnopoetry. Ethnopoetry is a research and writing technique that departs from standard social scientific representational method. Aitken $(2014,21)$ uses poetry in his ethnographic study to "provide a parsimonious rendering of emotions that exceeds the text" by pushing the words to "reveal the emotional power of a conversation" to get to the "embodied power that resides in people and places". It is an attempt to represent the non-representable of a story, in my story especially focusing on my own and others' emotions and embodied power.

Lucas felt like a treasure.

Hawaii, Tahiti, Wellington, Picton, United States of America; 
Lucas felt like a treasure to me.

I listened, carefully, closely, recording, writing, focusing, treasuring.

"Would you like tea?", an instance.

(I would like to focus on Lucas), "Sure"

Elaborate, scaled, detailed, like a treasure.

Iolanda: cups, cakes, tea, coffee, spaghetti

Lucas: symbols, marks, maps, movements, events - treasures!

Iolanda: cups, cakes, tea, coffee spaghetti, please taste!

As data they are selected,

discriminated for a purpose.

I need to focus on Lucas.

He was giving me evidence:

distant places and travels and treasures.

She returned with another cake, harder and harder, please taste!

"I would like to-focus-on-Lucas, please"

Local currencies, distances, flags, Newcastle.

I sat down with my treasure.

And that's when Kaden came back. An instance.

Lucas was drawing on my paper (Faculty of Business and Law)

Kaden was imitating on made-up paper,

imitating, insisting, annoying, playing.

I guess they hoped to be included. I do.

I quickly said "Nice" and "Sure". I did.

But Lucas. He felt like a treasure.

I was busy. Symbols, marks, movements, events, currencies, distances, flags.

Newcastle.

"Can you turn the paper for me too?", an instance.

I want to focus on Lucas. Need to.

Need.

Not breakdown, surprise, bewilderment or wonder.

Kaden and Iolanda left.

I had a treasure. Not breakdown, surprise, bewilderment or wonder.

No comment, fragment, note, object, face.

I left.

There is no division, in practice, between work

and

life.

Kaden's hands kept on drawing.

Long after I left.

I need to focus on Lucas, Kaden, your hands are not a treasure to me. 
Millei, Z. \& Rautio, P. (2017) 'Overspills' of research with children: an argument for slow research. Children's Geographies. http://dx.doi.org/10.1080/14733285.2016.1277182

Instances occur because the machinery for their production is culturally available.

My data needs are a machinery.

Watch out for those fingers Kaden!

[insert figure 1. here]

Figure 1. The home corner

[insert figure 2. here]

Figure 2. Lucas's map and trademarks and Kaden's trademarks

This is a reconstructed, even an invented event - with Ingold's (2011) 'intellectual craftmanship ${ }^{7}$ - where new relations are created so that the overspills 'fit within' the reframed representation. 'Intellectually crafting' is about the creation of new relations between the intended and reframed research events, my emotions and ethical dilemmas, and the inclusion of the earlier disrupting and ill-fitting elements that I was tempted to disregard: namely, the actions of Kaden, Iolanda and the adult staff members, and the objects: note papers, pens, table, chairs, cups and plates. Both relations: 'Home-education-care-homecorner' and 'Research-ethics-homecorner', have already been recognized by me as relevant and are crafted into the story with the help of knowledge of literature on early childhood education and research practice. Even though I have extended the frame of interpretation, this list remains selective of the multiplicity of other possible relations. I also acknowledge that each relation might also be a conjuncture of relations themselves thus simplifies the event.

\footnotetext{
7 Ingold draws on C. Wright Mills' idea of 'intellectual craft' in this concept. As a researcher tries to make sense of a situation they use different concepts and theories to test whether the situation is resolved. In this process there is no hard line between research, life, theory and methods, they come together as a whole person in a form of an intellectual craft.
} 
Millei, Z. \& Rautio, P. (2017) 'Overspills' of research with children: an argument for slow research. Children's Geographies. http://dx.doi.org/10.1080/14733285.2016.1277182

The relations are identified with a sociomaterial sensitivity (see more in Fenwick, Doyle, Michael \& Scoles 2015) and exemplified for instance in how Aitken and colleagues describe children constructing imaginaries about their world "as the product of interrelations constituted through spatial interactions, from the immensity of the global to the intimacy of the embodied" (Aitken, Lund \& Kjørholt, 2007, 13). These imaginaries are embodied material and discursive practices with objects and people. The reframed representation thus includes also those participants in children's everyday lives - relations, spaces, people and objects - that seemed to be spilling over the engagement and what was considered to be 'local' (so out of the frame of the original 'data'). When focusing on children's life in preschool for instance, their homes, policies, the newest Disney movie, appliances with trademarks or the recent influenza outbreak might seem spatially or contextually off but nevertheless play a part in children's life in the preschool. As children make their places in the preschool through their embodied material practices, they take up, make use of, and are being used by institutional and wider frames of these engagements - research included.

\section{Home-education-care-homecorner}

'Home', 'parents', 'offspring', a 'guest' or the 'family dog', their relations and material arrangements endow the home corner with meaning and make up the place. While the home corner is one of educational areas, as Taylor and Richardson (2005) explain: "by its own orthodoxy, home corner's stylised facade presents a classic vision of domestic utopia". The table with the lace tablecloth, chairs organised orderly around the round table, the miniature furniture surrounding, plastic and wooden food items, equipment and kitchen tools all mimic the home. "The familial play that occurs within the confines of home corner is assumed to be normal and natural, timeless and 
Millei, Z. \& Rautio, P. (2017) 'Overspills' of research with children: an argument for slow research. Children's Geographies. http://dx.doi.org/10.1080/14733285.2016.1277182

universal" (Taylor and Richardson, 2005). It is intimate and connects the space of the home corner with the home. In retrospect, framing my interactions with Lucas as 'an interview' and locating it in the home corner made little sense and so caused a wave of overspills. A home corner is just that to any participating human: a social, relaxed space where many things happen simultaneously. The materials available and the expected ways of behaving in a home corner supported what Kaden and Iolanda did: they were at home. It was me and Lucas actually, who spilled over the home corner.

The preschool is dominantly and historically understood in Australia as a place of education (learning) and care (Wong \& Press 2013, Wong \& Press 2013). The home corner is one of the established and well-defined areas for learning and care, others being a space for circle time, block corner, explorations area, reading corner, outside places and so on (Australian Children's Education and Care Quality Authority 2011). Policies and discourses of children's education and care might seem irrelevant to children's place-making practices. They are, however, firmly in place and reflected in the ways in which children actively settle to be cared for $^{8}$. The educators become sources of care for the children who expertly play their part as those to be cared for, listened to, being educated. Anyone who has tried to change an adult-led routine to a more child-initiated one in a preschool setting has felt this: children insist that the old roles are maintained. Iolanda's question "Would you like some tea?" was really no question: a "No" from me would have been ignored because I was to care for her and thus participate in what was a perfectly appropriate home corner practice. Kaden's insistence on doing the same that Lucas was doing for me - drawings - was a further

\footnotetext{
${ }^{8}$ See further on how socio-economic expectations and policies around educational care are actually shaping the preschool space in Gallagher (2013).
} 
Millei, Z. \& Rautio, P. (2017) 'Overspills' of research with children: an argument for slow research. Children's Geographies. http://dx.doi.org/10.1080/14733285.2016.1277182

reflection of how education and care were meant to be performed by a child. And so, again, what seemed to be spilling over were in fact relevant elements of the research.

\section{Research-ethics-homecorner}

The research engagement happened in the home corner, a place for 'free play'. Research agenda set by the researcher and children's free play were in contestation but also worked in tandem affording children to take more powerful positionings as 'free players' and as 'researched with rights'. Given all of this I was nevertheless adamant that Kaden was a distraction when he claimed to be doing research as well. I even tried to call his bluff.

'What are you doing?' - Kaden asked me. 'I am doing research' - I answered. 'Me too' - came the quick reply from Kaden. 'Do you know what research is, Kaden?' - I asked. 'I know and I am not telling you' - he replied.

Later on I repeatedly told Iolanda and Kaden that I wanted to do research with Lucas, in peace. Their disregard of my request to be able to concentrate on Lucas, Kaden's mimicking of Lucas' actions and of my position were all written off by me, initially, as irrelevant and a bit annoying: clear overspills. In retrospect my insistence on researching an individual child - one child at a time - isolated and focused, was the frame that caused the overspills. Had I attempted to grasp children's place-making beyond the focus on an individual child, and focused on dynamically evolving social and material layers of shared place-making, the actions of Iolanda and Kaden would have made me cheer in excitement (and definitely save me feeling less guilty of unequally treating all who are present). 
Millei, Z. \& Rautio, P. (2017) 'Overspills' of research with children: an argument for slow research. Children's Geographies. http://dx.doi.org/10.1080/14733285.2016.1277182

Due to focusing on children's place-making in a globalizing world, Lucas' game with global signs and symbols, and stories of international travel felt like a treasure: I wanted to give my full attention to what he said and did. Kaden begun to mimic Lucas' symbols. This to me at first seemed an unnecessary distraction, but in retrospect can be thought of as integral. Signs and symbols are such precisely because they are shared, mimicked, learnt, produced and reproduced; giving insights into the circulation of dynamisms of processes of globalization (Appadurai 1995). Just what Lucas and Kaden were doing in my presence. Place-making in a globalizing world through signs, exchange of knowledge about signs, brands, symbols -songs, catchy phrases, gestures - is at the core of children's cultures (Opie \& Opie 1969). We all connected through these symbols around the home corner kitchen table - Kaden's insistence on joining, even if he did not seem to know the signs (yet), circulated global signs in this event.

\section{Children's place-making in a globalizing world}

These are only some of the heterogeneous relations that invested the home corner with meaning as all of us engaged in place-making - me simultaneously researching the phenomenon. The ways in which different relations changed over time produced the 'surprise of space' for all of us (Massey 2005). Our place-making practices converged and diverged, sometimes conflicted and seemed like overspills: like distracting things that did not contribute to the research focus. When hanging on to what was about to spill over, clinging on and revisiting, a more dynamic image of the research focus evolved. One in which children's place-making in a globalizing world was no individual matter, neither local or global and most importantly: constantly and 
quite effortlessly made.

The focus on global signs, symbols and travels made our place a 'global' place in the home corner. Lucas performed 'the global' by talking about signs, explaining his journeys and asking me about where I was from. Kaden engaged in our 'game' and Iolanda supplied the food and drinks. I decided to teach him my mother tongue, Hungarian. Together, we were 'doing the global' in the home corner, in a similar way as Rose $(1997,316)$ explains that "researching gender is like 'doing gender"”. Thus, through our engagement with objects and ideas, researching 'the global' meant 'doing the global'. There is no prior reality to gain access to in children's views that might match any pre-defined notion of 'the global'. Rather, and to use Tsing's (2000) concept, we 'conjured' up and circulated 'the global' in our research engagement, since 'the global' "must be brought into being: proposed, practiced, and evaded as well as taken for granted" (Tsing 2000, 120). There is nothing that is given or ontological in 'the global'. And so, the overspills caused by Kaden and Iolanda, became seen as not distractions but integral parts of how 'the global' is made and circulated by children.

\section{An argument for slowing down research}

This paper contributes to arguments about broadening of what we include in the studies of children's everyday lives by slowing down research. But it also adds to considerations about the affective ways in which we produce and perform knowing, and that knowledge in research always includes the embodied, thinking and feeling humans (Thrift 2004, 61). Thinking, feeling, moral and political humans then create 
Millei, Z. \& Rautio, P. (2017) 'Overspills' of research with children: an argument for slow research. Children's Geographies. http://dx.doi.org/10.1080/14733285.2016.1277182

frames to do research that often limit what is possible to see, feel, think and note as research. This way things and people that misbehave might overspill the research engagement and open possibilities for new frames and methodologies (Michael 2012). Or as Brinkmann $(2014,724)$ clarifies, "The more one decides to 'collect data' in a methodological way or 'frame the data' within a preset theoretical framework", the less one can stumble upon objects, people and relations, and the more limited data remain both in its 'glow' and its potentiality to open up the researcher for continuous sense-making towards something new.

Against the practice of a linear research process and coding, Jackson \& Mazzei (2012) suggest to connect data, theory, method, representation and the becoming of the researcher with the use of Deleuze and Guattari's notion of 'machine' and 'plug in'. They use 'plug in' as a process where they make and unmake things as they plugin "ideas, fragments, theory, selves and sensations" into "literary machines: interview data, tomes of theory, conventional qualitative research methods books that [they] ... were working against ..." (Jackson \& Mazzei 2012, 1). Through the connectivity between 'reading-the-data-while-thinking-the-theory', data (story) and theory reciprocally create one another, different analytical concepts become useful, questions sprout and something new emerges. Plugging in different theories and concepts, emotions and fragments of data might help to make the cogs of research to jam, the research machine to break down, and force the researcher to rethink how he or she operates this machine in unhelpful ways.

Ingold's $(2011,240)$ idea of 'intellectual craftsmanship' is highly useful in destroying traditional divisions between 'theory', 'method', the researcher and everyday life. In 
producing and analysing research materials the 'whole person' of the researcher participates, including her ideas, selves, theories, sensations and feelings that assembled as learnings from her past. The researcher is a participant in social life and acts as an "everyday life researcher, she writes from her own participating stance in the social world" for purposes of living (Brinkman 2012, 18) and these purposes also frame the research engagements - empirically, conceptually, analytically and politically. And perhaps when 'data glows' or 'wonder' emerges from 'data', it is not only a sign that a space has opened for something new to emerge, but also a time to engage with one's purposes of living that frames research.

For children's geographies or childhood studies, the insights of this paper does not only point toward a need to be sensitive to one's emotions as a researcher, but also toward a careful going over of the research events as not means to an end but an end in themselves: the ongoing 'doing' of whatever the researched phenomenon is. Research events reflect and produce children's lives and the very phenomena we study. In this case 'the global' was produced at the research event and it was this production that I was a participant of, rather than extracting data from individual children. Slowing down research in order to catch and reconsider the overspills (Kaden's and Iolanda's actions, my feelings etc.) made me realize how 'the global' is in fact made and circulated by children: constantly, effortlessly and as a shared effort. 'The global' was not lodged in Lucas for an individual child is always "just" a participant in the shared and ongoing making of 'the global' by children and their social, material and affective surroundings. For Lucas' signs to be made into 'the global' the interest and actions of all involved were needed. 
Millei, Z. \& Rautio, P. (2017) 'Overspills' of research with children: an argument for slow research. Children's Geographies. http://dx.doi.org/10.1080/14733285.2016.1277182

The place of research is as much a place as the places we intend to focus as objectives of our research. The place of research is made up of numerous stories in their simultaneity, multiplicity and fluidity. The place of research therefore is not static, it is thrown together from stories people bring with them and make, that bring and create relations in place (Massey 2005). These ever changing stories and relations open the spaces of research for something new to emerge if we were prepared to slow down and experiment with stories (data) that glow.

\section{References}

Aitken, S.C. 2014. The Ethnopoetics of Space and Transformation. Young People's Engagement, Activism and Aesthetics. London: Routledge.

Aitken, S.C., Lund, R. \& Kjørholt, A. T. 2007. "Why Children? Why Now?" Children's Geographies 5(1-2): 3-14.

Ansell, N. 2009. "Childhood and the politics of scale: descaling children's geographies?" Progress in Human Geography 33(2) 190-209.

Appadurai, A. 1995. The production of locality. In Counterworks: Managing the diversity of knowledge, edited by R. Fardon, 204-225. London and New York: Routledge.

Beck, U. \& Beck-Gernsheim, E. 2002. Individualization Institutionalized Individualism and its Social and Political Consequences. London: SAGE Publications Ltd.

Brinkmann, S. 2014. "Doing without data." Qualitative Inquiry 20(6): 720-725.

Delanty, G. 2006. "The cosmopolitan imagination: critical cosmopolitanism and social theory." The British Journal of Sociology 57(1): 25-47.

Fenwick, T., Doyle, S., Michael, M. \& Scoles, J. 2015. Matters of Learning and Education Sociomaterial Approaches in Ethnographic Research. In MultiPluriTrans in Educational Ethnography: Approaching the Multimodality, Plurality and Translocality of Educational Realities, edited by Sabine Bollig, Michael-Sebastian Honig, Sascha Neumann, Claudia Seele, 141-162. Bielefeld: Verlag.

Gallagher, A. (2013) "At home in preschool care? Childcare policy and the negotiated spaces of educational care." Children's Geographies 11(2): 202-214.

Hadfield-Hill, S. \& Horton, J. 2014. "Children's experiences of participating in research: emotional moments together?” Children's Geographies 12(2): 135-153. 
Millei, Z. \& Rautio, P. (2017) 'Overspills' of research with children: an argument for slow research. Children's Geographies. http://dx.doi.org/10.1080/14733285.2016.1277182

Horton, J. \& Kraftl, P. 2006a. "Not just growing up, but going on: Materials, Spacings, Bodies, Situations.” Children's Geographies 4(3): 259-276.

Horton, J. \& Kraftl, P. 2006b. "What else? Some more ways of thinking and doing 'Children's Geographies'.” Children's Geographies 4(1): 69-95.

Horton, J., Kraftl, P. \& Tucker, F. 2008. "The challenges of 'Children's Geographies': a reaffirmation." Children's Geographies 6(4): 335-348.

Ingold, T. 2011. Being Alive: Essays on Movement, Knowledge and Description. London \& New York: Routledge.

Jackson, A., \& Mazzei, L. 2012. Thinking with Theory in Qualitative Research: Viewing Data Across Multiple Perspectives. Hoboken: Taylor \& Francis.

James, A. \& Prout, A. (Eds). 1997. Constructing and Reconstructing Childhood: Contemporary Issues in the Sociological Study of Childhood. Falmer Press: London.

Koro-Ljungberg, M. \& MacLure, M. 2013. "Provocations, Re-Un-Visions, Death, and other possibilities of "data'." Cultural Studies $\leftrightarrow$ Critical Methodologies 13(4): 219222.

Kullman, K. \& Palludan, C. 2011. "Rhythmanalytical sketches: agencies, school journeys, temporalities." Children's Geographies 9(3-4): 347-359.

Law, J. \& Mol, A. 2002. Complexities. Social studies of knowledge practices. Durham, NC: Duke University Press.

MacLure, M. 2013. "The Wonder of Data." Cultural Studies - Critical Methodologies 13(4): 228-232.

Massey, D. 1991. “A global sense of place.” Marxism Today (38): 24-29.

Massey, D. 2005. For Space. London, UK: Sage

Michael, M. 2012. “'What Are We Busy Doing?': Engaging the Idiot.” Science, Technology, \& Human Values 37(5): 528-554.

Pyer, M. 2008. "Unintended Consequences? Exploring the un(fore)seen effects and outcomes of research." Children's Geographies 6(2): 213-217.

N. Pyyry 2015. "'Sensing with' photography and 'thinking with' photographs in research into teenage girls' hanging out." Children's Geographies 13(2): 149-163.

Rautio, P. 2013. "Children who carry stones in their pockets: on autotelic material practices in everyday life." Children's Geographies 11(4): 394-408.

Revsbæk, L. \& Tanggaard, L. 2015. “Analyzing the present.” Qualitative Inquiry 21(4): 376-387.

Rose, G. 1997. "Situating knowledges: positionality, reflexivities and other tactics." Progress in Human Geography 21(3): 305-320. 
Millei, Z. \& Rautio, P. (2017) 'Overspills' of research with children: an argument for slow research. Children's Geographies. http://dx.doi.org/10.1080/14733285.2016.1277182

St. Pierre, E. A. 2011. Post-qualitative research. In The Sage handbook of qualitative research edited by N. Denzin \& Y. Lincoln, (6 ${ }^{\text {th }}$ edition) 611-626. New York, NY: SAGE.

St. Pierre, E. A. 2013. “The appearance of data.” Cultural Studies $\leftrightarrow$ Critical Methodologies 13(4): 223-227.

Taylor, A., \& Richardson, C. 2005. Queering home corner. Contemporary Issues in Early Childhood 6:163-174.

Thrift, N. 2004. Intensities of Feeling: Towards a Spatial Politics of Affect. Geografiska Annaler Series B: Human Geography 86(1): 57-78.

Tsing, A. 2000. Inside the Economy of Appearances. Public Culture Winter 12(1): 115-144.

Wong, S., \& Press, F. 2013. Integrated early childhood services in Australian early childhood education and care: What can we learn from our past? Australian Journal of Social Issues 47(2): 153-173. 